\title{
MODELING ENVIRONMENTAL IMPACT OF MACHINERY SECTORS TO PROMOTE SUSTAINABLE DEVELOPMENT OF THAILAND
}

\author{
Pruethsan Sutthichaimethee ${ }^{1}$ \\ 1 Department of Environmental Science, Faculty of Science, Burapha University, Chonburi, 20131, Thailand, \\ e-mail: pruethsan@gmailc.com
}

Received: 2015.09.16

Accepted: 2015.12.09

Published: 2016.01 .06

\begin{abstract}
The objective of this research is to propose an indicator to evaluate environmental impacts from the machinery sectors of Thailand, leading to more sustainable consumption and production in this sector of the economy. The factors used to calculate the forward linkage, backward linkage and real benefit included the total environmental costs. The highest total environmental cost was railway equipment need to be resolved immediately because it uses natural resources in carrying capacity, higher than standard environmental cost, and contribute to low real benefit. Electric accumulator \& battery, secondary special industrial machinery, motorcycle, bicycle \& other carriages, and engines and turbines need to monitor closely because they are able to link to other production sectors more than other production sector do and they have high environmental cost. In order to decide the sustainable development strategy of the country, there is a need to use this research to support decision-making.
\end{abstract}

Keywords: machinery sectors, total environment cost, carrying capacity, forward linkage, real benefit, backward linkage.

\section{INTRODUCTION}

Thailand' economy has developed rapidly. Machinery industry has been expanding continuously from $2.74 \%$ in 1999 to $33.79 \%$ in 2014 . As a result, Gross Domestic Product [GDP] per capita has been constantly increasing as it is shown in figure 1 [NESDB 2015] and urban areas continues to grow. Furthermore, tourism industry expanded together with Machinery industry. It gives the advantage to the economics of the country, whose current economics has improved because the amount of capital steadily flows in the economic system. Moreover, many investors from other countries came to invest in Thailand, which is rational for the economics of the country [NESDB 2015]. However, Businesses and consumers are the major players in the economic system [Kennedy et al. 2007, Liang and Zhang 2009, Li et al. 2012]. Consumers want to gain high utilization under limited budgets, whereas businesses aim to maximize their profit and re- duce expenditures [Lenzen 1998, Hugo and Pistikopoulos 2005, Pantavisid 2012]. Neither party pays attention to the environmental cost, causing over-consumption and over-production [TDRI 2007, Duchin 2008, Benoit 2009, Chen et al. 2010, ADB 2014]. However, the sustainable development for the country should develop in three dimensions, collectively [Adams 2009, Ukaga et al. 2010, Yigitcanlar and Dizdaroglu 2015], namely economic, social, and environmental dimension. Previously, Thailand gave priority to developing only the economic growth. Moreover, the National Economic and Social Development Board [2015] stated that firms did not consider the cost from natural resources materials, energy and transportation, fertilizer and pesticides, and sanitary and similar services, which represent environmental costs. As a result, Thailand did not achieve sustainable development because economic growth goes together with higher environmental cost [Brent et al. 2006, Grossmann 2009, Duque et al. 2010]. 


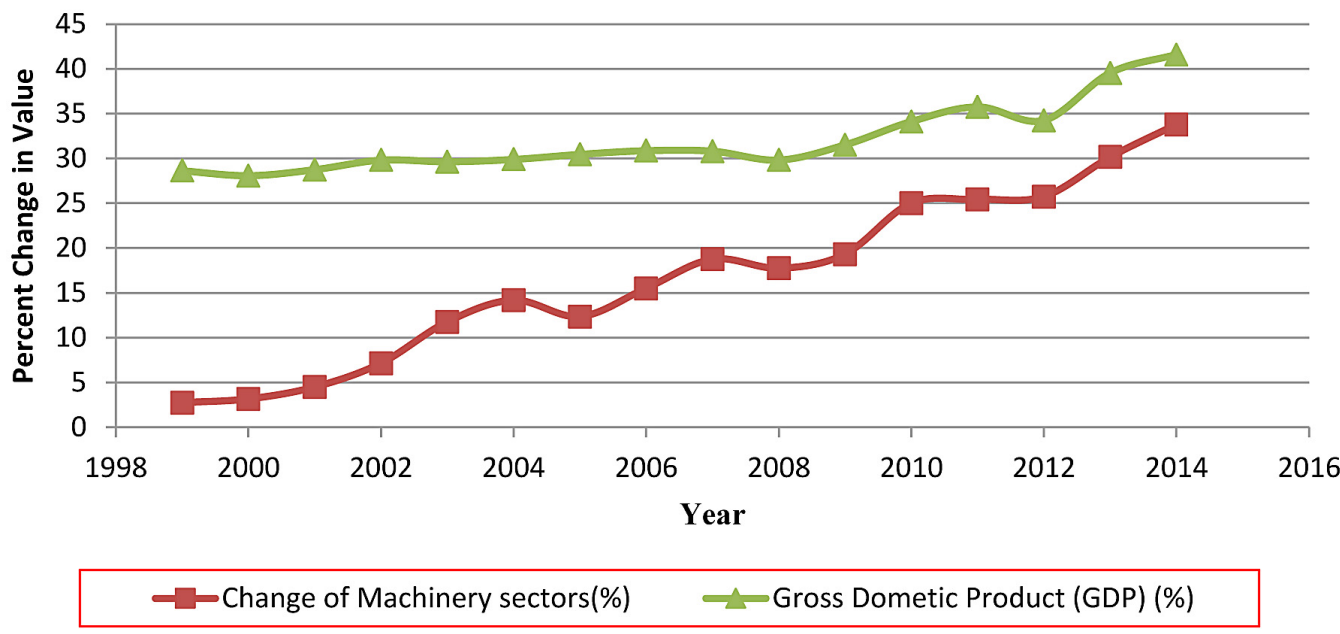

Figure 1. The relationship between changing rate of machinery industry and the ratio of production to GDP

The machinery sector represents the main occupation for many people in Thailand, and it consistently generates high income to the country [TDRI 2007, NESDB 2014]. At the same time, the Asian Development Bank [2015] found that the Machinery sector has been using environmental and natural resources at an increasingly high rate, compared with other sectors of the economy. Thus, the government must give increased attention to managing environmental problems caused by the Machinery sector, because this production sector influences the economic growth of the country [NESDB 2014, ADB 2014]. Moreover, the government should prioritize its efforts by considering the income and cost of economic sectors in proportion to their scale. Finally, they should prepare solutions to deal with problems and trends that might occur in the future [ADB 2014, TDRI 2014, NESDB 2015].

Accordingly, the formulation of policy and strategies to develop the country must concern Real Benefit and Total Environmental Costs in the three above mentioned areas [Bodini 2002, TDRI 2005, Ness et al. 2007, Salema et al. 2010, Ukaga et al. 2010, ADB, 2014, NESDB 2015]. In addition, prioritizing of environmental problems should be clearly defined [ADB 2014]. All of these factors could be included in an index to indicate environmental problems and lead to sustainable solutions in the future, which is the main emphasis of this research.

\section{Objectives}

To propose an indicator to evaluate environmental impacts from the machinery sector of Thailand, leading to more sustainable con- sumption and production in this sector of the economy.

\section{Scope of study}

The environmental and natural resource costs are calculated for each machinery sectors using data from Thailand's input-output table. The calculation uses input data categorized as natural resource materials, energy and transportation, fertilizer and pesticides, and sanitary and similar services. The effects from consumption of the services are not included in environmental cost.

The main calculations in this study use data from the input-output table of Thailand for 2015, which are the most current data. The precision of the calculations is limited by economic and social descriptions used to create the input-output table.

\section{Conceptual framework}

The conceptual framework (Figure 2) for selection of product sectors for evaluating their Shadow Environmental Cost is based on aims and concepts of sustainable development [NESDB 2015, ADB 2014]. Three supporting concepts are welfare economics of A.C. Pigou [Pigou 1960, Zhang 2012, ADB 2014], natural resource economics, and ecology economics [Yigitcanlar and Dizdaroglu 2015, Zhang 2012].

\section{MATERIALS AND METHODS}

The model in this study is related to the inputoutput table, in which the relationship of the data is categorized by rows and columns as follows 


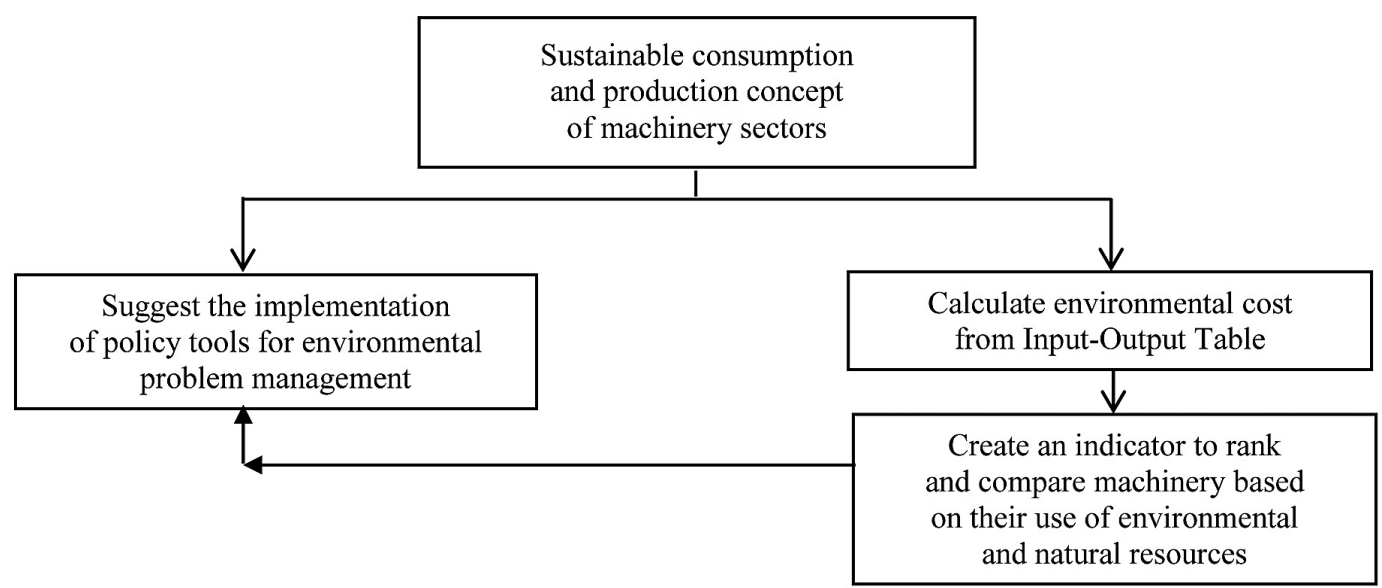

Figure 2. Conceptual framework

Table 1. Matrix used to create the input-output table of production sectors

\begin{tabular}{|c|c|c|c|c|c|c|c|c|}
\hline \multirow{2}{*}{\multicolumn{2}{|c|}{ Producing sector }} & \multicolumn{2}{|c|}{ Processing sectors } & & \multirow{2}{*}{\multicolumn{3}{|c|}{ Final demand }} & \multirow{3}{*}{\begin{tabular}{|c|}
$\begin{array}{c}\text { Total outputs } \\
{[\mathrm{X}]}\end{array}$ \\
$x_{1}$ \\
\end{tabular}} \\
\hline & & \multirow{2}{*}{$\begin{array}{c}1 \\
x_{11}\end{array}$} & \multirow{2}{*}{$\frac{2}{x_{12}}$} & & & & & \\
\hline \multirow{2}{*}{$\begin{array}{l}\text { Processing } \\
\text { sectors }\end{array}$} & 1 & & & $c_{1}$ & $i_{1}$ & $g_{1}$ & $e_{1}$ & \\
\hline & 2 & $x_{21}$ & $x_{22}$ & $c_{1}$ & $i_{2}$ & $g_{2}$ & $e_{2}$ & $x_{2}$ \\
\hline \multirow{3}{*}{$\begin{array}{l}\text { Payments } \\
\text { sectors }\end{array}$} & \multirow{2}{*}{ Value added } & $l_{1}$ & $I_{2}$ & $I_{c}$ & $I_{1}$ & $I_{g}$ & $l_{\mathrm{e}}$ & L \\
\hline & & $n_{1}$ & $n_{2}$ & $n_{c}$ & $n_{1}$ & $n_{g}$ & $n_{\mathrm{e}}$ & $\mathrm{N}$ \\
\hline & Imports & $m_{1}$ & $m_{2}$ & $m_{\mathrm{c}}$ & $m_{1}$ & $m_{\mathrm{g}}$ & $m_{\mathrm{e}}$ & M \\
\hline \multicolumn{2}{|c|}{ Total outlays [X'] } & $x_{1}$ & $x_{2}$ & C & 1 & G & $E$ & $\mathrm{X}$ \\
\hline
\end{tabular}

in Table 1 [Leontief 1986, Karna and Engstrom 1994, Lee et al. 2009].

The rows present output distribution of product sector $i$ for $n$ product sectors and the gross product of product sector $i$ can be defined, for $1 \leq i \leq n$, by:

$$
X_{i}=\sum_{j=1}^{n} X_{i j}+F_{i}
$$

where: $X_{i}$ - refers to gross product of product sector $i$,

$X_{i j}$ - refers to product distribution of product sector $i$ of goods and services production for product sector $j$,

$F_{i}-$ refers to the final demand of product sector $i$.

Columns show the structure of expense or cost of goods production for product sector $j\left(X_{i}\right)$ that can be defined, for $1 \leq j \leq \mathrm{n}$, by:

$$
X_{i}=\sum_{j=1}^{n} X_{i j}+V_{j}
$$

where: $V_{j}$ - refers to value added of product sector $j$, only if input value is directly proportional to output value.

Then $X_{i j}$ can be defined by the relationship of output $(X)$, input coefficient $(A)$ and final demand $(F)$ of production structure for an economic system that can be defined by:

$$
\begin{gathered}
X=A X+F \\
X=[I-A]^{-1} F
\end{gathered}
$$

where: $[I-A]^{-1}$ is the Leontief inverse matrix (or inverse matrix) [Leontief 1936], which is important for economic system analysis when using the input-output table.

The inverse matrix acts as a direct and indirect input coefficient of a production supply chain that can be used for supply chain length and intensity calculation. Environmental cost of the production of each good or service can be calculated using the multiplication of the environmental cost coefficient and the inverse matrix. Finally, the result represents the total effect of a supply chain by giving the accumulated environmental cost of each good produced. The result also shows the intensity of backward environmental effects of direct and indirect inputs and outputs. Furthermore, the result presents names, sectors and intensities of environmental costs that are useful to formulate an efficient policy and for solving environmental problem [Leontief 1986, Lave et al. 1995]. 
Relationships in the input-output table affects the output of each product sector $(\Delta F)$, which is called the multiplier for final goods and services. Equation 5 presents the calculation of the multiplier:

$$
\Delta X=[I-A]^{-1} \Delta F
$$

If the final demand $(\Delta F)$ increases, environmental cost will increase $(\Delta E)$. Equation 6 calculates the increase of environmental cost:

$$
\Delta E=R[I-A]^{-1} \Delta F
$$

\section{RESULTS AND DISCUSSION}

The results of the environmental costs, real benefit, and forward linkage are classified by each category of the production. This research can be summarized as following:

Table 2 lists the top ten machinery sectors in terms of forward linkage, backward linkage, real benefit, and total environmental cost. Real benefit is the revenue for a sector, minus the environmental costs. The average real benefit was 0.871 . If the real benefit for a given industry is lower than average, it can be considered to represent a loss, while the values higher than average represents profit. The average value for total environmental cost was 0.07 . If the cost for a particular industry is lower than the average, there is a further capacity for production. Environmental cost values that are higher than the average signifies that there is no further capacity for production.

Highlights from the findings include the following:

1. The machinery sectors with the highest total environmental cost was railway equipment. The cost index was above average, signifying that this sector does not have a capacity for further production. In contrast, the lowest total environmental cost was radio and television.

2. The highest real benefit in the machinery sectors was ship building, while the lowest real benefit was radio and television. The lowest real benefit could signify loss in profit.

3. The highest forward linkage in the machinery sectors was railway equipment, while the lowest forward linkage was radio and television.

4. The highest backward linkage in the machinery sectors was electric accumulator and battery, while the lowest backward linkage was aircraft.
This research is a pilot study of environmental costs of production of services in the economic system of Thailand, using the input-output database to account for differences among sectors. Environmental cost contributes to damage to the environment and is affected by the behavior and decisions of producers, consumers, and the government [Bailey et al. 2004, Benoit 2009, ADB 2014, TDRI 2015]. The environmental cost cannot be estimated from the activities occurring in the market alone. Instead, the estimation of the environmental cost of each production sector in Thailand needs to incorporate shadow environmental cost, which reflects environmental cost [ADB 2014, Pantavisid 2012, TDRI 2007]. The information can be used to compare the environmental cost of production sectors, and could help to create an environmental problem management indicator [McMullan 2013, ADB 2014]. The shadow environmental cost modeled in this study relies on four groups of economic data, including costs of natural resources materials, energy and transportation, fertilizer and pesticides, and sanitary and similar services [TDRI 2005, Pantavisid 2012, ADB 2007].

The results of this examination of environmental costs by each sector is consistent with the research of Zhang [2010], Pantavisid [2012], and the results of the real benefit analysis is also consistent with the research of Sanguanwongthong [2013], TDRI [2007]. From the research we found that when comparing the average and the result from the comparison, there are 15 sectors in environmental costs of natural resource material has a higher value than the cost of average criteria. Likewise, 16 sectors of energy and transportation, 7 sectors of fertilizer and pesticide, and 12 sectors of sanitary and similar service found that the result from the research are higher than the average. Thus, from the past, Thailand did not take an interest in such environmental costs indicator, which led to damage of the environmental and natural resources because of used over carry capacity.

The highest environmental costs are railway equipment, motorcycle, bicycle and other carriages, agricultural machinery, and electric accumulator and battery. They give a negative impact to the environmental and natural resources. The government must reduce environmental cost and announce protection scheme not affecting in the future, which should contain with proactive and reactive strategy. Proactive strategy is utilizing 
Table 2. Top ten machinery sectors ranked by forward linkage, real benefit, and environmental costs

\begin{tabular}{|c|c|c|c|c|c|c|c|}
\hline $\begin{array}{l}\text { Forward } \\
\text { linkage }\end{array}$ & Product sector & $\begin{array}{c}\text { Backward } \\
\text { linkage }\end{array}$ & Product sector & $\begin{array}{l}\text { Real } \\
\text { benefit }\end{array}$ & Product sector & $\begin{array}{c}\text { Total } \\
\text { environ- } \\
\text { mental cost }\end{array}$ & Product sector \\
\hline 0.59 & Railway equipment & 0.97 & $\begin{array}{l}\text { Electric accumulator } \\
\text { and battery }\end{array}$ & 0.54 & Ship building & 0.18 & Railway equipment \\
\hline 0.55 & $\begin{array}{l}\text { Motorcycle, bicycle } \\
\text { and other carriages }\end{array}$ & 0.89 & $\begin{array}{l}\text { Special industrial } \\
\text { machinery }\end{array}$ & 0.47 & $\begin{array}{l}\text { Repairing of motor } \\
\text { vehicle }\end{array}$ & 0.11 & $\begin{array}{l}\text { Motorcycle, bicycle } \\
\text { and other carriages }\end{array}$ \\
\hline 0.53 & $\begin{array}{l}\text { Other electrical } \\
\text { apparatuses and } \\
\text { supplies }\end{array}$ & 0.73 & $\begin{array}{l}\text { Motorcycle, bicycle } \\
\text { and other carriages }\end{array}$ & 0.45 & $\begin{array}{l}\text { Agricultural } \\
\text { machinery }\end{array}$ & 0.11 & $\begin{array}{l}\text { Agricultural } \\
\text { machinery }\end{array}$ \\
\hline 0.52 & $\begin{array}{l}\text { Engines and } \\
\text { turbines }\end{array}$ & 0.53 & $\begin{array}{l}\text { Engines and } \\
\text { turbines }\end{array}$ & 0.43 & $\begin{array}{l}\text { Special industrial } \\
\text { machinery }\end{array}$ & 0.11 & $\begin{array}{l}\text { Electric accumulator } \\
\text { and battery }\end{array}$ \\
\hline 0.52 & Ship building & 0.46 & $\begin{array}{l}\text { Office and } \\
\text { household } \\
\text { machinery }\end{array}$ & 0.43 & $\begin{array}{l}\text { Motorcycle, bicycle } \\
\text { and other carriages }\end{array}$ & 0.10 & $\begin{array}{l}\text { Special industrial } \\
\text { machinery }\end{array}$ \\
\hline 0.48 & $\begin{array}{l}\text { Repairing of motor } \\
\text { vehicle }\end{array}$ & 0.45 & $\begin{array}{l}\text { Radio and } \\
\text { television }\end{array}$ & 0.43 & $\begin{array}{l}\text { Insulated wire and } \\
\text { cable }\end{array}$ & 0.10 & $\begin{array}{l}\text { Engines and } \\
\text { turbines }\end{array}$ \\
\hline 0.46 & $\begin{array}{l}\text { Household electrical } \\
\text { appliances }\end{array}$ & 0.43 & Motor vehicle & 0.42 & Engines and turbines & 0.10 & Ship building \\
\hline 0.46 & Motor vehicle & 0.40 & Railway equipment & 0.41 & $\begin{array}{l}\text { Other electrical } \\
\text { apparatuses and } \\
\text { supplies }\end{array}$ & 0.10 & $\begin{array}{l}\text { Household electrical } \\
\text { appliances }\end{array}$ \\
\hline 0.46 & $\begin{array}{l}\text { Agricultural } \\
\text { machinery }\end{array}$ & 0.40 & $\begin{array}{l}\text { Agricultural } \\
\text { machinery }\end{array}$ & 0.39 & $\begin{array}{l}\text { Electric accumulator } \\
\text { and battery }\end{array}$ & 0.09 & $\begin{array}{l}\text { Wood and metal } \\
\text { working machinery }\end{array}$ \\
\hline 0.46 & $\begin{array}{l}\text { Wood and metal } \\
\text { working machinery }\end{array}$ & 0.40 & Ship building & 0.38 & Railway equipment & 0.09 & $\begin{array}{l}\text { Other electrical } \\
\text { apparatuses and } \\
\text { supplies }\end{array}$ \\
\hline
\end{tabular}

eco-friendly input and process (green growth), while reactive strategy is to improve the law, especially Pulloters Pays Principle [PPP], to perform effectively and efficiently with offenders.[TDRI 2007, ADB 2014, Pantavisid 2012, Zhang 2010]

From the analysis, thus, railway equipment have the highest environmental problem. Moreover, it generates low revenue, which leads to low real benefit. This production sector must resolve the problem immediately because the calculated value, higher than standard value that resulted in carrying capacity. It is not only railway equipment of meat that ought to solve the problem urgently but also other 9 sectors in a sequence also need to resolve the problem. If the problem is not solved urgently, it is difficult to do in the future and contribute to huge damage. When comparing environmental problem with real benefit we found that 10 having problem sectors did not give high real benefit. Consequently, the government should pay attention to agricultural sector and service sector or other sector because both of them generate high income to the country with low environmental cost. However, Thailand must monitor closely to sectors having potential to have environmental problem in short time by seeing the environmental cost. All of them highly link to the economic leading to over consumption in necessary environmental natural resources [Zhang 2010, ADB 2014].
Thailand must monitor closely sectors having potential to have environmental problem in short time by seeing the backward linkage value. The top 10 backward linkage are electric accumulator and battery, secondary special industrial machinery, motorcycle, bicycle and other carriages, engines and turbines, office and household machinery, radio and television, motor vehicle, railway equipment, agricultural machinery, and ship building. All of them are highly linked to the economic leading to over consumption of necessary natural resources [ADB 2014].

The results of this research could also be applied to environmental problem management under the sustainable production concept with a limitation of administrative resources. It leads to efficient environmental consumption by the society [TDRI 2007]. The classification of natural resources and environmental capital of the whole system can be implemented at the micro level [ADB 2014], while the classification from green value added and the forward linkage is for decision making at a macro level [NESDB 2015, TDRI 2007, Zhang 2012, ADB 2014]. Consequently, using the correct data allows for efficient environmental problem-solving [TDRI 2007].

Thailand and other ASEAN countries have not created an indicator of environmental problems using real benefit, environmental cost, and 
environmental problems, and this has led them to formulate ineffective policies and plans for their countries [ADB 2014]. More developed countries, like Japan and European countries, give importance to environmental stewardship, and their efforts can be reflected in higher green GDP. This methodology would help Thailand formulate efficient policy and forecast future conditions more accurately, allowing the nation to deal with crises arising from environmental problems [TDRI 2007, Sanguanwongthong 2013].

\section{CONCLUSIONS}

Railway equipment is highest environmental problem and environmental cost it generates produce low real benefit. Besides, they use environmental natural resources over their carrying capacity. However, other 9 production sectors also need to be considered immediately because all of them are also using environmental and natural resources over carrying capacity. Electric accumulator and battery must monitor closely. Railway equipment have the highest environmental cost. The government must find solution to reduce such costs in order to increase real benefit, which is advantageous to Thailand. In the past, Thailand did not give importance to environmental cost that led to economic crisis many times. Consequently, the result of this operation can be used to support economic planning of the country and management guideline for the country.

\section{Acknowledgements}

This work was performed with the approval of the Burapha University and Office of the National Economic and Social Development Board.

\section{REFERENCES}

1. Adams W.M. 2009. Green Development: Environment and Sustainability in the Third World ( $2^{\text {nd }}$ ed.). New York, Rutledge.

2. Asian Development Bank (ADB) 1997. Emerging Asia and Challenges. Manila, Asian Development Bank.

3. Asian Development Bank (ADB) 2014. Environment, climate change and disaster risk management. Manila, Asian Development Bank.

4. Bailey R., Bras B., Allen J.K. 2004. Applying ecological input-output flow analysis to material flows in industrial systems. Part I. Tracing flows. J. Ind.
Ecol., 8(1), 45-68.

5. Benoit 2009. Guidelines for Social Life Cycle Assessment of Products. UNEP-SETAC, G. GuillénGosálbez.

6. Bodini A. 2002. Building a systemic environmental monitoring and indicators for sustainability: What has the ecological network approach to offer? Ecol. Indic. 2012, 15, 140-148.

7. Bodini A., Bondavalli C. 2002. Towards a sustainable use of water resources: A whole-ecosystem approach using network analysis. Int. J. Environ. Pollut. 2002, 18(5), 463-485.

8. Bojarski J., Laínez A., Espuña, L., Puigjaner. 2009. Incorporating environmental impact and regulations in a holistic supply chains modeling. An LCA approach, Comput. Chem. Eng., 33(10), 1747-1759.

9. Brent C., Labuschagne C. 2006. Social indicators for sustainable project and technology life cycle management in the process industry. Int. J. Life Cycle Assessment, 11(1), 3-15.

10. Brunner P.H. 2007. PH. Reshaping urban metabolism. J. Ind Ecol 2007, 11(2), 11-13.

11. Chen D.J. 2003. Analysis, integration and complexity study of industrial ecosystems. Doctoral dissertation, Beijing, Tsinghua University.

12. Chen ZM., Chen GQ., Zhou JB., Jiang MM., Chen B. 2010. Ecological input-output modeling for embodied resources and emissions in Chinese economy 2005. Commun Nonlinear SciNumer Simul 2010, 15(7), 1942-1965.

13. Duchin F. 2008. Input-output economics and material flows. In: Suh S, editor. Handbook of inputoutput economics in industrial ecology. Cheltenham, Edward Elgar Publishing. Ltd.

14. Duque J., Barbosa-Povoa, APFD Novais A.Q. 2010. Design and planning of sustainable industrial networks: Application to a recovery network of residual products. Industrial and Engineering Chemistry Research, 49(9), 4230-4248.

15. Espinosa A., Walker J. 2011. A Complexity Approach to Sustainability: Theory and Application. London, Imperial College Press.

16. Goedkoop M., Heijungs R., Huijbregts M., Schryver A.D., Struijs J., Van Zelm R. 2009. A life cycle impact assessment method which comprises harmonized category indicators at the midpoint and the endpoint level. The Hague, Ministry of VROM. ReCiPe., First edition.

17. Grossmann I.E. 2009. Optimal design and planning of sustainable chemical supply chains under uncertainty. American Institute of Chemical Engineers J., 55(1), 99-121.

18. Hammond A., Adriaanse A., Rodenburg E., Bryant D., Woodward R. 1995. Environmental indicators: A systematic approach to measuring and reporting 
on environmental policy performance in the context of sustainable development. World resources institute.

19. Harwick J.J., Olewiler N.D. 1998. The Economics of natural resource use. Massachusetts, AddisonWesley.

20. Huang S.L., Hsu W.L. 2003. Materials flow analysis and energy evaluation of Taipei's urban construction. Landsc Urban Plan, 63(2), 61-74.

21. Hugo A., Pistikopoulos E.N. 2005. Environmentally conscious long-range planning and design of supply chain networks. J. of Cleaner Production, 13(15), 1471-1491.

22. Karna A., Engstrom J. 1994. Life-cycle analysis of newsprint: European scenarios. Paperi ja Puu, 76(4), 232-237.

23. Kennedy C., Cuddihy J., Engel-Yan J. 2007. The changing metabolism of cities. J. Ind. Ecol., 11(2), 43-59.

24. Lave L.B., Cobas-Flores E., Hendrickson C.T., McMichael F.C. 1995. Using input-output analysis to estimate economy-wide discharges. Environmental Science and Technology, 29(9), 420-426.

25. Lee C.L., Huang S.L., Chan S.L. 2009. Synthesis and spatial dynamics of socio-economic metabolism and land use change of Taipei Metropolitan Region. Ecol. Model., 220(21), 2940-2959.

26. Lenzen M. 1998. Primary energy and greenhouse gases embodied in Australian final consumption: An input-output analysis. Energy Policy, 26(6), 495-506.

27. Leontief W.W. 1936. Quantitative input and output relation in the economic system of the United State. Review of Economics and Statistics, 18(3), 105-125.

28. Leontief W.W. 1986. Input-output economics. $2^{\text {nd }}$ ed. New York, Oxford University Press.

29. Li S.S., Zhang Y., Yang Z.F., Liu H, Zhang J.Y. 2012. Ecological relationship analysis of the urban metabolic system of Beijing, China. Environ. Pollut., 170, 169-176.

30. Li Y., Chen B., Yang Z.F. 2009. Ecological network analysis for water use systems: a case study of the Yellow River Basin. Ecol, Model,, 220(22), 3163-3173.

31. Liang S., Zhang T. 2011. Urban metabolism in China: achieving dematerialization and decarbonization in Suzhou. J. Ind. Ecol., 15(3), 420-434.

32. Marull J., Pino J., Tello E., Cordobilla M.J. 2010. Social metabolism, landscape change and land-use planning in the Barcelona metropolitan region. Land Use Policy, 27(2), 497-510.

33. McMullan C. 2013. Indicators of urban ecosystem health. Retrieved from http://archive.idrc.ca/ecohealth/indicators_e.html.
34. Ness E., Urbel-Piirsalu S., Anderberg, L., Olsson 2007. Categorising tools for sustainability assessment. Ecological Economics, 60(3), 498-508.

35. Office of the National Economic and Social Development Board 2015. National income of Thailand, 2015. Bangkok, NESDB.

36. Office of the Prime Minister 2007. Budget document: expenditure budget for fiscal year Ministry of Public Health. Vol. 3. Bangkok, Bureau of the Budget.

37. Pantavisid S. 2012. Natural resource and environmental costs of good and service production via sustainable consumption and production approach towards prioritizing the environmental management in Thailand. Doctoral dissertation. Social Development and Environmental Management, School of Social and Environmental Development, National Institute of Development Administration.

38. Pigou A.C. 1960. The economics of welfare. $4^{\text {th }}$ ed, London, Macmillan.

39. Pinto-Varela A.P., Barbosa-Póvoa A., Novais. 2011. Bi-objective optimization approach to the design and planning of supply chains: Economic versus environmental performances. Computers and Chemical Engineering, 35(8), 1454-1468.

40. Salema M.I.G., Barbosa-Povoa A.P., Novais A.Q. 2010. Simultaneous design and planning of supply chains with reverse flows: A generic modelling framework. European J. of Operational Research, 203(2), 336-349.

41. Sanguanwongthong N. 2013. Study of environmental costs for the evaluation of industrial development in Thailand. Doctoral dissertation. Social Development and Environmental Management, School of Social and Environmental Development, National Institute of Development Administration.

42. Simpson D.R., Bradford R.L. 1996. Taxing variable cost: environmental regulation as industrial policy. J. of Environmental Economics and Management, 30(30), 282-300.

43. Su M.R., Yang Z.F., Chen B., Ulgiati S. 2009. Urban ecosystem health assessment based on energy and set pair analysis - a comparative study of typical Chinese cities. Ecol Model, 220(18), 2341-2348.

44. Thailand Development Research Institute (TDRI). 2006. Prioritizing Issues in Natural Resources and Environmental Management. Final report prepared the Thailand Health Fund. Bangkok.

45. Thailand Development Research Institute (TDRI). 2007. Prioritizing Environmental Problems with Environmental Costs. Final report prepared the Thailand Health Fund. Bangkok.

46. Ukaga O., Maser C., Reichenbach M. 2010. Sustainable Development: Principle, Frameworks and Case Studies. London, CRC Press Taylor and Frances Group. 
47. Xu, M. 2010. Development of the physical input monetary output model for understanding material flows within ecological-economic systems. J. Res. Ecol., 2(1), 123-134.

48. Yigitcanlar T., Dur D., Dizdaroglu D. 2015. Towards prosperous sustainable cities: a multiscalar urban sustainability assessment approach, Habitat Int., 45(1), 36-46.

49. Yigitcanlar T., Dizdaroglu D. 2015. Ecological approaches in planning for sustainable cities: A review of the literature. Global J. Environ. Sci. Manage., 1(2), 159-188.

50. Yu Y.J. 2008. Syndromic city illnesses diagnosis and urban ecosystem health assessment. Acta Ecol Sin, 28(4), 1736-1747.

51. Zhang Y. 2013. Urban metabolism: A review of research methodologies. Environ Pollut 2013, 178, 463-473.

52. Zhang Y., Li S.S., Fath B.D., Yang Z.F., Yang N.J.
2011. Analysis of an urban energy metabolic system: comparison of simple and complex model results. Ecol. Model., 22(1), 14-19.

53. Zhang Y., Liu H., Li Y., Yang Z.F., Li S.S., Yang N.J. 2012. Ecological network analysis of China>s societal metabolism. J Environ Manage, 93(1), 254-263.

54. Zhang Y., Yang Z.F., Fath B.D. 2010. Ecological network analysis of an urban water metabolic system: model development and a case study for Beijing. Sci Total Environ 2010a, 408(20), 4702-4711.

55.Zhang Y., Yang Z.F., Fath B.D., Li S.S. 2010. Ecological network analysis of an urban energy metabolic system: model development, and a case study of four Chinese cities. Ecol. Model., 221(16), 1865-1879.

56. Zhang Y., Zhao Y.W., Yang Z.F., Chen B., Chen G.Q. 2009. Measurement and evaluation of the metabolic capacity of an urban ecosystem. Common Nonlinear. Sci. Numer. Simul., 14(4), 1758-1765. 